\title{
FORMATION OF NATIONAL TEAMS TAKING INTO ACCOUNT THE FACTORS OF FOOTBALL PLAYERS' CLUB MIGRATION
}

\author{
Eduard Sobol $^{1 \mathrm{ABE}}$, Andrii Svatyev ${ }^{1 \mathrm{CD}}$, Igor Doroshenko $^{1 \mathrm{CDE}}$, \\ Svitlana Kokareva ${ }^{2 \mathrm{BCE}}$, Nataliya Korzh ${ }^{2 \mathrm{BCE}}$, Eduard Doroshenko ${ }^{3 \mathrm{ABCD}}$ \\ 'Zaporizhzhia National University \\ ${ }^{2}$ National University "Zaporizhzhia Polytechnic" \\ ${ }^{3}$ Zaporizhzhia State Medical University
}

Corresponding Author: Eduard Doroshenko, E-mail: doroe@ukr.net Accepted for Publication: December 15, 2021

Published: December 25, 2021

DOI: $10.17309 / \mathrm{tmfv} .2021 .4 .15$

\begin{abstract}
Purpose. To determine the parameters of club migration of highly skilled legionary footballers when forming national teams for participation in official international competitions.

Materials and methods. Population: 496 highly skilled football players - participants of the 2022 World Cup group stage qualifiers.

Results. The winning national teams with high UEFA coefficients have a smaller percentage of legionnaires than the group of winning teams with lower UEFA coefficients: $45.05 \%$ (coefficient 3.8) and 85.94\% (coefficient 14.8), respectively. The indicators of dual citizenship have no significant impact on the formation of national teams, although the national teams of Wales, Turkey, and Scotland showed rather high values - $9(32.14 \%), 7(28.00 \%)$, and $5(20.00 \%)$ of football players, respectively. Legionary footballers from the top six European leagues (England, Spain, Italy, Germany, France, Portugal) account for $87.50 \%$ of the total number of legionnaires who participated in the 2022 World Cup group stage qualifiers.

Conclusions. Migration processes have an impact on the development of football at various levels of functioning: children and youth, reserve, student, amateur, semi-professional, and professional. Club migration, which is typical of highly skilled legionary footballers, has an indirect impact on the formation of national teams.

Keywords: football, migration, ranking, formation, national team.
\end{abstract}

\section{Introduction}

Modern problems of training highly skilled football players are inextricably linked with the nature of their development at various levels of functioning: children and youth, reserve, amateur, semi-professional, and professional. Researchers note a significant influence of migration factors, which are caused by football players' desire to continue athletic training in a top professional club or league, on the processes of their training (Borysova, 2013; Sushko, 2018). Today, footballers' migration is widespread at the reserve and professional levels. In addition, in modern European football and in the United States, footballers' migration has become widespread at the semi-professional level - in youth teams, minor professional leagues, student championships, etc.

Naturally, these processes have an impact on the formation of teams, both at the club and national team levels. This,

(c) Sobol, E., Svatyev, A., Doroshenko, I., Kokareva, S., Korzh, N., \& Doroshenko, E., 2021. in turn, increases the relevance of correcting the training of national teams, taking into account the ratio of football players representing professional clubs of national and foreign championships (leagues) in their composition. In this context, the most informative indicators for selecting candidates for national teams are those of presence (absence) of constant competitive practice in a club, its level and intensity. It is also important to take into account the athlete's individual characteristics, which are related to the nature and speed of recovery processes in their body (Mykhaliuk, Sivolap, Horokhovskyi, Potapenko, 2021).

The problematic issues of training football players, which are associated with migration processes, have relatively recently become the subject of study by specialists. The studies by Poli $(2006,2010,2019)$ analyzed in detail the historical, geographical, and socio-cultural prerequisites for the emergence of African footballers' migration to European professional leagues and national championships. The author emphasizes the importance of migration processes, 
which are closely connected with the management, training and competitive performance of a professional club. Similar results were obtained in a sociological study (Storey, 2019) investigating the national allegiance and sporting citizenship as factors of identity choices of African footballers.

In modern football, there is a concentration of highly qualified athletes in top European championships and professional leagues: "Barclays Premier League" (England), "Liga de Fútbol Profesional, Primera División" (Spain), "Lega Nazionale Professionisti Serie A TIM" (Italy), "FußballBundesliga" (Germany), and "Le championnat de France de football" (France).

Economic studies (Gubaydullina, 2018; Solntsev, 2020) testify that football is a global brand more than other sports. In addition, the global factors of migration of highly skilled football players are the economic basis for the development of football as the number one sport.

The study by Campenhout, Sterkenburg, and Oonk (2019) analyzed the data of 4,761 football players from fifteen national teams that took part in World Cups (1930-2018), including the data of 301 foreign-born footballers. The results of the study show that the absolute number of foreignborn footballers who have participated in World Cups is constantly increasing. This testifies to the intensification of migration processes among highly skilled football players for participation in official international competitions.

The study by Campenhout and Sterkenburg (2019) examines the diversification of the compositions of national football teams. In particular, it proposed and described the idea of using "migration corridors" for changing athletes' nationality (naturalization) with a further opportunity to play for the national team of a country.

The study by Lago-Peñas C., Lago-Peñas S., Lago I. (2019) investigated the relationship between the factors of football players' migration and the performance of certain athletes and teams. The authors focus on positive and negative psychological factors in sports teams comprising foreign footballers (migrants). In particular, the authors highlight the need to use psychodiagnostic and corrective techniques to create an optimal psychological climate in a team that consists of footballers playing in national and foreign championships (leagues).

The problems of globalization of student football in the United States are examined in the study by Kirk and Weaver (2019). The authors highlight the peculiarities associated with talented football players' migration to North American student football leagues - a high development level of infrastructure and financial support, on the one hand, and the complex legal procedure of implementing a full or partial "naturalization" in the US migration system, on the other hand. In addition, the results of the study which examines students' motivation to attend student football matches and focuses on additional interest of young people in the games of teams comprising migrant footballers seem promising (Namethe, Naido, \& Heerden, 2021).

The studies by Esposito, D'Elia, Raiola (2020), Sulistiyono, Akhiruyanto, Primasoni (2021) show that the integrated use of methods for developing athletes' intelligence, personal qualities and game skills of team interactions in youth football can, indirectly, contribute to the intensification of physical fitness, manifestations of early game specialization and, as a result, promote young football players' migration at the national and international level.
From the point of view of the general theory of sports and the system of athletic training (Platonov \& Essentaev, 2015; Platonov, 2016, 2018), the processes of athletes' migration are among extra-training and out-of-competition factors. However, it is the factors of migration that increase the level of sports competition and, as a result, improve the effectiveness and spectacularity of the competitive process. This concept is especially relevant for team sports, including football (Kostiukevych, Imas, \& Borysova, 2018). Additionally, there is a need to correct the traditional approaches in the management of training and competitive activity of highly skilled football players, taking into account migration factors (Kostiukevych, Shchepotina, \& Vozniuk, 2020; Shchepotina, Kostiukevych, Asauliuk, et al., 2021).

This concept increased the interest of researchers in the problems of athletes' migration (Sushko \& Doroshenko, 2016), they focused on the need to correct the traditional approaches in the training process in team sports, taking into account the following factors:

- peculiarities of the formation of sports teams (Doroshenko, Sobol, \& Doroshenko, 2018);

- migration of highly skilled athletes and coaches (Doroshenko \& Sobol, 2018; Sushko \& Melnik, 2019);

- financial and logistical support of migration processes at the level of national championships and professional football leagues (Sobol, Svatyev, \& Doroshenko, 2021);

- financial and logistical support of migration processes at the level of participation of athletes of national teams in the European (UEFA), world (FIFA) championships, international tournaments (UEFA Champions League, UEFA Europa League, UEFA Europa Conference League) and compliance of their participants with the Financial Fair Play Regulations (Sobol, Svatyev, \& Doroshenko, 2021).

In our opinion, despite a significant number of studies devoted to addressing the topical issues of migration of highly skilled football players in the context of the formation of national teams, the following problems have not been finally resolved:

- the principles of forming the national team, taking into account the differentiation of athletes into typological groups - first team, extended team, promising reserve;

- taking into account the peculiarities of the competitive practice of athletes - candidates for the national team at the club level - championship ranking, quantitative indicators of the competitive practice, possibility of differentiating the game specialization, etc.

That is why this study focuses on investigating the processes of migration of highly skilled football players - candidates for national teams.

Hypothesis. Taking into account the indicators of club migration of highly skilled football players is a criterion for the formation of national teams that will help to efficiently correct the training process when there is a lack of time for full preparation.

The purpose of the study is to determine the parameters of club migration of highly skilled legionary footballers when forming national teams for participation in official international competitions. 


\section{Material and methods}

\section{Study participants}

The ascertaining experiment examined the parameters of the competitive activity of highly skilled football players (496 athletes) - members of the national teams that won the 2022 World Cup group stage qualifiers (10 teams). In addition, the parameters of the competitive activity of players of the national teams that placed second in the group stage qualifying tournaments (10 teams) were studied. This gives the right to participate in further qualifying games.

\section{Organization of the study}

Experimental studies were carried out from March 24 to November 16, 2021 during the group stage of the 2022 World Cup qualifiers. The study examined the entry forms, the indicators of presence in the national teams of legionary footballers participating in competitions of foreign professional leagues (championships), considered the factors of presence or absence of dual citizenship among athletes. Based on data from the open sources and official websites of UEFA (www.uefa.com), the national professional leagues of England (www.premierleague.com), Spain (www.laliga.es), Italy (www.legaseriea.it), Germany (www.bundesliga.com), France (www.liguel.fr), etc., the study determined the indicators of football players' club migration in the context of the formation of national teams, analyzed the quantitative indicators of migration processes, taking into account the factors of dual citizenship of athletes. On the basis of the obtained experimental data, the study considered the possibilities of efficient correction of the training of highly qualified football players, taking into account the quantitative and qualitative indicators of the club competitive practice of athletes.

\section{Methods of research}

Analysis and generalization of data from scientific and methodological literary sources and the Internet, pedagogical observations, content analysis of materials from the official websites of national professional football leagues (associations), the official website of UEFA, pedagogical ascertaining experiment, methods of mathematical statistics.

\section{Statistical analysis}

During the experimental research, the methods of mathematical statistics were used to determine the following calculated indicators: arithmetic mean, percentage, calculated ratios (scored and missed goals).

\section{Results}

To analyze and interpret the experimental data, the study defined the statistical indicators of 10 national teams that won the 2022 World Cup group stage qualifiers and earned the right to participate in the final tournament. In addition, the study defined the statistical indicators of 10 national teams that placed second in the 2022 World Cup group stage qualifiers and earned the right for further participation in qualifying matches. The data obtained, taking into account the UEFA coefficients, are given in Table 1.

The study determined the percentage of highly skilled footballers with dual citizenship ("naturalized" athletes) in the national teams, and the percentage of highly skilled le-

Table 1. Key performance indicators of technical and tactical actions of highly skilled footballers (legionnaires) and the UEFA club ranking of national teams in the 2022 World Cup qualifiers, $n=496$

\begin{tabular}{|c|c|c|c|c|c|c|}
\hline UEFA Country Ranking & G & Pts & $\mathrm{P} / \mathrm{G}$ & GS & GM & $\mathbf{S} / \mathbf{M}$ \\
\hline 1. England & 10 & 26 & 2.6 & 39 & 3 & 13 \\
\hline 2. Spain & 8 & 19 & 2.4 & 15 & 5 & 3 \\
\hline 3. Italy & 8 & 16 & 2.0 & 13 & 2 & 6.5 \\
\hline 4. Germany & 10 & 27 & 2.7 & 36 & 4 & 9 \\
\hline 5. France & 8 & 18 & 2.3 & 18 & 3 & 6 \\
\hline 6. Portugal & 8 & 17 & 2.1 & 17 & 6 & 2.8 \\
\hline 7. Netherlands & 10 & 23 & 2.3 & 33 & 8 & 4.1 \\
\hline 9. Scotland & 10 & 23 & 2.3 & 17 & 7 & 2.4 \\
\hline 10. Russia & 10 & 22 & 2.2 & 19 & 6 & 3.2 \\
\hline 11. Ukraine & 8 & 12 & 1.5 & 11 & 8 & 1.4 \\
\hline 12. Serbia & 8 & 20 & 2.5 & 18 & 9 & 2 \\
\hline 13. Belgium & 8 & 20 & 2.5 & 25 & 6 & 4.2 \\
\hline 14. Switzerland & 8 & 18 & 2.3 & 15 & 2 & 7.5 \\
\hline 15. Croatia & 10 & 23 & 2.3 & 21 & 4 & 5.3 \\
\hline 18. Turkey & 10 & 21 & 2.1 & 27 & 16 & 1.7 \\
\hline 20. Denmark & 10 & 27 & 2.7 & 30 & 3 & 10 \\
\hline 23. Sweden & 8 & 15 & 1.9 & 12 & 6 & 2 \\
\hline 27. Poland & 10 & 20 & 2.0 & 30 & 11 & 2.7 \\
\hline 47. North Macedonia & 10 & 18 & 1.8 & 23 & 11 & 2.1 \\
\hline 50. Wales & 8 & 15 & 1.9 & 14 & 9 & 1.6 \\
\hline
\end{tabular}

Note: G - games; Pts - points; P/G - points per game; GS - goals scored; GM - goals missed; S/M - ratio of scored and missed goals. 
Table 2. Indicators of club migration of highly skilled football players in the context of the formation of national teams in the 2022 World Cup qualifiers, $\mathrm{n}=496$

\begin{tabular}{|c|c|c|c|c|c|c|c|c|}
\hline \multirow{2}{*}{ UEFA Country Ranking $\left(^{\star}\right)$} & \multirow{2}{*}{ Group } & \multirow{2}{*}{$\mathbf{F}$} & \multirow{2}{*}{$\mathbf{Q}$} & \multirow{2}{*}{$\mathbf{E}$} & \multicolumn{2}{|c|}{ Dual Citizenship } & \multicolumn{2}{|c|}{ Legionnaires } \\
\hline & & & & & $\mathbf{n}$ & $\%$ & $\mathbf{n}$ & $\%$ \\
\hline Serbia: 29.375 (12) & $\mathrm{A}$ & + & - & 26 & 4 & 15.38 & 24 & 92.31 \\
\hline Portugal: 47.549 (6) & A & - & + & 24 & 4 & 16.67 & 18 & 75.00 \\
\hline Spain: 85.713 (2) & $\mathrm{B}$ & + & - & 23 & 1 & 4.35 & 12 & 52.17 \\
\hline Sweden: 22.875 (23) & $\mathrm{B}$ & - & + & 26 & 2 & 7.69 & 17 & 65.38 \\
\hline Switzerland: 27.925 (14) & $\mathrm{C}$ & + & - & 25 & 1 & 4.00 & 21 & 84.00 \\
\hline Italy: 69.045 (3) & $\mathrm{C}$ & - & + & 23 & 2 & 8.70 & 4 & 17.39 \\
\hline France: 49.915 (5) & $\mathrm{D}$ & + & - & 23 & 2 & 8.70 & 16 & 69.57 \\
\hline Ukraine: 31.400 (11) & $\mathrm{D}$ & - & + & 25 & 0 & 0.00 & 7 & 28.00 \\
\hline Belgium: 29.000 (13) & $\mathrm{E}$ & + & - & 24 & 1 & 4.17 & 21 & 87.50 \\
\hline Wales: $5.500(50)$ & $\mathrm{E}$ & - & + & 28 & 9 & 32.14 & 18 & 64.29 \\
\hline Denmark: 24.175 (20) & $\mathrm{F}$ & + & - & 22 & 0 & 0.00 & 20 & 90.91 \\
\hline Scotland: 32.700 (9) & $\mathrm{F}$ & - & + & 25 & 5 & 20.00 & 16 & 64.00 \\
\hline Netherlands: 39.900 (7) & G & + & - & 26 & 1 & 3.85 & 16 & 61.54 \\
\hline Turkey: 25.100 (18) & G & - & + & 25 & 7 & 28.00 & 13 & 52.00 \\
\hline Croatia: 25.400 (15) & $\mathrm{H}$ & + & - & 24 & 3 & 12.50 & 18 & 75.00 \\
\hline Russia: 32.682 (10) & $\mathrm{H}$ & - & + & 27 & 2 & 7.41 & 4 & 14.81 \\
\hline England: 95.096 (1) & I & + & - & 26 & 0 & 0.00 & 3 & 11.54 \\
\hline Poland: 15.875 (27) & I & - & + & 26 & 0 & 0.00 & 25 & 96.15 \\
\hline Germany: 66.784 (4) & $\mathrm{J}$ & + & - & 23 & 1 & 4.35 & 7 & 30.43 \\
\hline North Macedonia: 7.000 (47) & $\mathrm{J}$ & - & + & 25 & 2 & 8.00 & 8 & 32.00 \\
\hline
\end{tabular}

Note: ${ }^{\star}$ - current position in the ranking; $\mathrm{F}$ - first place in the group; Q - second place in the group (participation in qualifying matches); E - entry form; Legionnaires - footballers of the national team who play in foreign championships (leagues)

gionary footballers who play in foreign national championships (professional leagues). The results are presented in Table 2, taking into account the quantitative indicators of the UEFA ranking.

The percentage of the internal structure of club migration of highly skilled legionary footballers was determined, taking into account the indicators of the current UEFA ranking (for national championships or professional leagues).

Group A. The Serbia national team: in the entry form, there are 24 legionnaires representing professional football clubs of different countries (Italy (3) - 7 (29.20\%); Spain (2) 6 (25.00\%); Portugal (6) - 3 (12.50\%); France (5) - 3 (12.50\%); England (1) - 1 (4.16\%), Germany (4) - $1(4.16 \%)$, the Netherlands (7) - 1 (4.16\%), Poland (27) - 1 (4.16\%), Russia (10) - 1 $(4.16 \%))$. The Portugal national team: in the entry form, there are 18 legionnaires who represent professional football clubs (England (1) - 9 (50.00\%); France (5) - 3 (16.67), Spain (2) - 3 (16.67\%); Germany (4) - 2 (11.11\%); Italy (3) - 1 (5.55\%)).

Group B. The Spain national team: 12 legionnaires (England (1) - 10 (83.33\%); Portugal (6) - 2 (16.67\%)). The Sweden national team: 17 legionnaires (England (1) -5 (29.41\%); Italy (3) - 4 (23.53\%); Germany (4) - 2 (11.77\%), Spain (2) - 2 (11.77\%); Scotland (9) - 1 (5.88\%), the Netherlands (7) - 1 (5.88\%), Norway (21) - 1 (5.88\%), Russia $(10)-1(5.88 \%))$.
Group C. The Switzerland national team: 21 legionnaires (Germany (4) - 12 (57.14\%); France (5) - 2 (9.53\%), Italy (3) - 2 (9.53\%); Turkey (18) - 1 (4.76\%), Greece (19) - 1 (4.76\%), Portugal (6) - 1 (4.76\%), Scotland (9) - 1 (4.76\%), England (1) - $1(4.76 \%))$. The Italy national team: 4 legionnaires (France (5) - 3 (75.00\%); England (1) - 1 (25.00\%)).

Group D. The France national team: 16 legionnaires (England (1) - 5 (31.25\%); Germany (4) - 4 (25.00\%), Italy (3) -4 (25.00\%); Spain (2) - 3 (18.75\%)). The Ukraine national team: 7 legionnaires (England (1) - 2 (28.60\%); Belgium (13) - 1 (14.28\%), Hungary (28) - 1 (14.28\%), Italy (3) -1 (14.28\%), Portugal (6) - 1 (14.28\%), Poland (27) - 1 $(14.28 \%))$

Group E. The Belgium national team: 21 legionnaires (England (1) - 6 (28.58\%); Germany (4) - 4 (19.04\%); Spain (2) - 3 (14.29\%), France (5) - 3 (14.29\%); Italy (3) - 2 (9.52\%); Portugal (6) - 1 (4.76\%), Turkey (18) - 1 (4.76\%), Qatar - $1(4.76 \%))$. The Wales national team: 18 legionnaires (England (1) - 15 (83.33\%); Italy (3) - 2 (11.11\%); Germany (4) $-1(5.56))$.

Group F. The Denmark national team: 20 legionnaires (England (1) - 7 (35.00\%); Italy (3) - 5 (25.00\%); Germany (4) - 3 (15.00\%); Spain (2) - 2 (10.00\%); France (5) - 1 (5.00\%), the Netherlands (7) - 1 (5.00\%), Turkey (18) - 1 $(5.00 \%))$. The Scotland national team: 16 legionnaires 
Table 3. Summary indicators of participation of highly skilled legionary footballers in the 2022 World Cup group stage qualifiers, $\mathrm{n}=288$

\begin{tabular}{|c|c|c|}
\hline $\begin{array}{c}\text { Championship (league, association), } \\
\text { UEFA ranking }\left(^{\star}\right)\end{array}$ & Legionnaires, $\mathbf{n}$ & Legionnaires, \% \\
\hline England (1) & 96 & 33.22 \\
\hline Spain (2) & 26 & 8.99 \\
\hline Italy (3) & 51 & 17.65 \\
\hline Germany (4) & 39 & 13.49 \\
\hline France (5) & 24 & 8.30 \\
\hline Portugal (6) & 16 & 5.54 \\
\hline Total: & 252 & 87.50 \\
\hline
\end{tabular}

(England (1) - 14 (87.50\%); Belgium (13) - 1 (6.25\%), Cyprus (17) $-1(6.25 \%))$.

Group G. The Netherlands national team: 16 legionnaires (Italy (3) - 5 (31.25\%); England (1) - $3(18.75 \%)$; Spain (2) $-3(18.75 \%)$, Germany (4) - 3 (18.75\%); France (5) $-1(6.25 \%)$, Belgium (13) - $1(6.25 \%))$. The Turkey national team: 13 legionnaires (France (5) - $4(30.77 \%)$, Italy (3) - 4 (30.77\%); England (1) - 3 (23.08\%); Belgium (13) - 1 (7.69\%), the Netherlands (7) - $1(7.69 \%))$.

Group H. The Croatia national team: 18 legionnaires (Germany (4) - 6 (33.34\%); Italy (3) - 4 (22.24\%); England (1) - 3 (16.67\%); France (5) - 1 (5.55\%); Spain (2) - 1 (5.55\%), Russia (10) - 1 (5.55\%), Scotland (9) - 1 (5.55\%), Turkey (18) - $1(5.55 \%))$. The Russia national team: 4 legionnaires (Germany (4) - 1 (25.00\%), Italy (3) - $1(25.00 \%)$, France (5) - 1 (25.00\%), Turkey (18) - $1(25.00 \%)$ ).

Group I. The England national team: 3 legionnaires (Italy (3) - 2 (66.67\%); Spain (2) - $1(33.33 \%)$ ). The Poland national team: 25 legionnaires (Italy (3) - 8 (32.00\%); England (1) - 7 (28.00\%); Germany (4) - 4 (16.00\%); Greece (19) - 2 (8.00\%); France (5) - 1 (4.00\%), the USA - $1(4.00 \%)$, Ukraine (11) - 1 (4.00\%), Russia (10) - $1(400 \%)$ ).

Group J. The Germany national team: 7 legionnaires (England (1) - 4 (57.13\%); France (5) - 1 (14.29\%), Spain (2) - 1 (14.29\%), Austria (8) - 1 (14.29\%)). The North Macedonia national team: 8 legionnaires (Croatia (15) - 2 (25.00\%); Spain (2) - 1 (12.50\%), Italy (3) - 1 (12.50\%), Ukraine (11) - 1 (12.50\%), Moldova (33) - 1 (12.50\%), Turkey (18) - 1 (12.50\%), Sweden (23) - $1(12.50 \%))$.

Based on the obtained results, the summary indicators of highly skilled legionary footballers were calculated, taking into account their participation in foreign national championships (professional football leagues) (Table 3).

In addition, 36 legionnaires who participated in the 2022 World Cup group stage qualifying matches represent professional football leagues from 17 countries: the Netherlands, Austria, Scotland, Russia, Ukraine, Belgium, Croatia, Cyprus, Turkey, Greece, Norway, Sweden, Poland, Hungary, Moldova, Qatar, the USA. In these championships (professional football leagues), there are from one to six athletes, which is a range of values from 0.34 to $2.08 \%$.

\section{Discussion}

The experimental data given in Table 1 may point to a statistical relationship between the indicators of the UEFA ranking for the national championship (professional league, association) and the indicators of the competitive activity of highly skilled footballers - participants of the 2022 World Cup group stage qualifiers. Most of the national teams that placed first in their qualifying groups (Table 2) have a high UEFA coefficient for the national championship: national teams of England (95.096; ranking - 1); Spain (85.713; ranking - 2); Germany (66.784; ranking - 4); France (49.915; ranking - 5); the Netherlands (39.900; ranking - 7). In addition to them, the winners of the group stage qualifiers are the teams with lower UEFA coefficients for the national championship: Serbia (29.375; ranking - 12), Belgium (29.000; ranking - 13), Switzerland (27.925; ranking - 14), Croatia (25.400; ranking - 15), and Denmark (24.175; ranking 20). At the same time, the following tendency is observed: in the entry forms of national teams with high UEFA coefficients, there is, as a rule, a smaller percentage of highly skilled legionary footballers: the average number of legionnaires in the teams of England, Spain, Germany, France, and the Netherlands is $45.05 \%$ (with an average UEFA coefficient -3.8). In the group of winning teams of the 2022 World Cup group stage qualifiers with a lower UEFA coefficient (Serbia, Belgium, Switzerland, Croatia, and Denmark), the average number of legionnaires is $85.94 \%$ (with an average UEFA coefficient - 14.8).

From the group of teams with a high UEFA coefficient, the national teams of Italy (69.045; ranking - 3), Portugal (47.549; ranking - 6), Scotland (32.700; ranking - 9), Russia (32.682; ranking - 10), Ukraine (31.400; ranking - 11) won second places in the qualifying tournaments and received the right to participate in further qualifying matches. The Austria national team (34.650, ranking - 8) failed in the qualifying group stage. The teams with lower UEFA coefficients for national championships (professional leagues) also placed second in the 2022 World Cup group stage qualifiers: Turkey (25.100; ranking - 18), Sweden (22.875; ranking - 23), Poland (15.875; ranking - 27), North Macedonia (7.000; ranking - 47), Wales (5.500; ranking - 50). There is a tendency: in the entry forms of the group of national teams with higher UEFA coefficients, there is a smaller percentage of highly skilled legionnaires: the average number of legionnaires in the teams of Italy, Portugal, Scotland, Russia, Ukraine is $39.84 \%$ (with an average UEFA coefficient - 7.8). In the group of teams that placed second in the 2022 World Cup group stage qualifiers with a lower UEFA coefficient (Turkey, Sweden, Poland, North Macedonia, Wales), the average number of legionnaires is $61.96 \%$ (with an average UEFA coefficient - 33). 
According to the indicators of dual citizenship among highly skilled football players - participants in the 2022 World Cup group stage qualifiers, there were no statistically significant differences or linear trends. The highest indicators were observed in the national teams of Wales ( 9 athletes), Turkey (7 athletes), and Scotland (5 athletes).

In addition, the quantitative and qualitative indicators of highly skilled legionary footballers who represent the top European championships (professional leagues) are of importance. Table 3 shows the indicators of six European championships (professional leagues), whose players account for $87.50 \%$ of the total number of legionary footballers. Worthy of note are the indicators of the leading European professional league: Barclays Premier League (England) 96 highly skilled players out of 288 (33.22\%) legionnaires. It is likely that these indicators determine successful performance of the English professional football clubs and the England national team in official international competitions. Today, Barclays Premier League (England) has the highest concentration of highly qualified football players in European football championships (professional leagues), which, indirectly, contributes to an increase in the level of internal competition and, as a result, an increase in the level of athletic proficiency and effectiveness of the competitive process (Sobol, Svatyev, \& Doroshenko, 2021).

In connection with the above, the controversial issues regarding the correction of the training of highly skilled legionary footballers seem relevant. The study by Sushko (2018) focuses on the need to differentiate legionary footballers into typological groups when forming national teams: first team, regular substitution, extended team, promising reserve. In turn, this differentiation requires taking into account the factors of the competitive practice of highly skilled legionnaires at the club level, its quantitative and qualitative indicators: the level of the championship (professional league), performances in official international competitions (UEFA Champions League, UEFA Europa League, UEFA Europa Conference League). A comprehensive analysis of these factors, taking into account the level of competitive loads and individual indicators of athletes' recovery, creates prerequisites for efficient correction of the national team training (Platonov, 2016, 2018). In addition, this helps to define a set of information characteristics to specify the starting lineup and players to come off the bench in case a quick correction of the competitive process is needed (Sushko \& Melnik, 2019). The study by Shchepotina et al. (2021) shows that this set of information characteristics creates opportunities for managing not only the competitive process, but also the training of football players in professional football clubs. This is of relevance when forming national teams.

\section{Conclusions}

The analysis of literature data and other information sources shows that migration processes have an impact on the development of football at various levels of functioning: children and youth, reserve, student, amateur, semi-professional, and professional.

Club migration processes, which are typical of highly skilled legionary footballers, have an indirect impact on the formation of national teams.
Based on the analysis of the materials of the 2022 World Cup group stage qualifiers, the following trends were identified: the winning national teams with high UEFA coefficients have a smaller percentage of legionnaires than the group of winning teams with lower UEFA coefficients: $45.05 \%$ (coefficient 3.8 ) and $85.94 \%$ (coefficient 14.8 ), respectively. The indicators of dual citizenship have no significant impact on the formation of national teams, although the national teams of Wales, Turkey, and Scotland showed rather high values 9 (32.14\%), $7(28.00 \%)$, and $5(20.00 \%)$ of football players, respectively.

Legionary footballers from the top six European leagues (England, Spain, Italy, Germany, France, Portugal) account for $87.50 \%$ of the total number of legionnaires who participated in the 2022 World Cup group stage qualifiers.

\section{Disclosure statement}

No author has any financial interest or received any financial benefit from this research.

\section{Conflict of interest}

The authors state no conflict of interest.

\section{References}

Borysova, O.V. (2013). Profesijnyj sport: perspektyvy rozvytku v Ukrayini (na materiali tenisu). Slobozhanskyj naukovosportyvnyj visnyk, 1(34), 29-34. http://journals.uran.ua/ index.php/1991-0177/article/view/17952

Doroshenko, E.Yu., Sobol, E.O., \& Doroshenko, I.E. (2018). Komplektaciya futbolnyx komand ukrayinskoyi Premyerligy v konteksti globalizaciyi sportu vyshhyx dosyagnen. Fizychna kultura, sport ta zdorovya naciyi, (6), 129-135. http://eprints.zu.edu.ua/28156/

Doroshenko, E.Yu., \& Sobol, E.O. (2018). Faktory migraciyi v konteksti vplyvu na rezultatyvnist zmagalnoyi diyalnosti kvalifikovanyx futbolistiv. Naukovyj chasopys NPU im. M.P. Dragomanova "Naukovo-pedagogichni problemy fizychnoyi kultury (fizychna kultura i sport)", 9(103), 5154. http://enpuir.npu.edu.ua/handle/123456789/21671

Platonov, V.N., \& Essentaev, T.K. (2015). Organyzacyonnoupravlencheskye modely sovershenstvovanyya systemu podgotovky sportsmenov vusokoj kvalyfykacyy $\mathrm{v}$ uslovyyax polytyzacyy y kommercyalyzacyy olympyjskogo sporta. Nauka v olympyjskom sporte, (2), 19-26. https://sportnauka.org.ua/en/wp-content/uploads/ nvos/articles/2015.2_3.pdf

Platonov, V.N. (2016). Obshhaya teoryya podgotovky sportsmenov: ystoryya razvytyya, metodologyya postroenyya, sovremennoe sostoyanye. Nauka $v$ olympyjskom sporte, (3), 75-104. https://sportnauka.org. ua/wp-content/uploads/nvos/articles/2016.3_10.pdf

Platonov, V.N. (2018). Struktura y soderzhanye neposredstvennoi podhotovky sportsmenov vusokoi kvalyfykatsyy k hlavnum sorevnovanyiam. Nauka $v$ olympyiskom sporte, (2) 17-41. https://sportnauka.org.ua/ wp-content/uploads/nvos/articles/2018.2_2.pdf

Sushko, R.O., \& Doroshenko, E.Yu. (2016). Hlobalizatsiia v suchasnomu sviti ta yii vplyv na sport vyshchykh 
dosiahnen. Sportyvnyi visnyk Prydniprovia, (2), 140-145. http://infiz.dp.ua/misc-documents/2016-02/2016-02-28.pdf

Sushko, R.O. (2018). Ekspertna otsinka problemnykh pytan pidhotovky i shliakhiv rozvytku sportyvnykh ihor v umovakh dii hlobalnykh chynnykiv. Naukovyi chasopys NPU im. M.P. Drahomanova "Naukovopedahohichni problemy fizychnoi kultury (fizychna kultura i sport)", 3(97), 111-115. http://enpuir.npu.edu.ua/ handle/123456789/20889

Sushko, R.O., \& Melnyk, D.M. (2019). Mihratsiia u systemi pidhotovky futbolistiv vysokoi kvalifikatsii (na materiali chempionativ Ukrainy). Naukovyi chasopys NPU imeni M.P. Drahomanova "Naukovo-pedahohichni problemy fizychnoi kultury (fizychna kultura i sport)", 10(118), 135141. http://enpuir.npu.edu.ua/handle/123456789/26994

Gubaydullina, F.S. (2018). Global Trends in World Football: the Economist's View. Journal of International Economic Affairs, 8(3), 499-516. https://doi.org/10.18334/eo.8.3.39215

Esposito, G., D’Elia, F., \& Raiola, G. (2020). A Method to Promote the Development of Intelligence and Game Skills in Youth Football. Teoriâ ta Metodika Fizičnogo Vihovannâ, 20(3), 142-148. https://doi.org/10.17309/tmfv.2020.3.03

Kirk, R., \& Weaver, A. (2019). Footballers, Migrants and Scholars: the Globalization of US Men's College Soccer. Journal Soccer \& Society, 20(6), 781-794. https://doi.org/10.1080/14660970.2017.1419469

Kostiukevych, V., Imas, Ye., Borysova, O., Dutchak, M., Shynkaruk, O., Kogut, I., Voronova, V., Shlonska, O., \& Stasiuk, I. (2018). Modeling of the Athletic Training Process in Team Sports During an Annual Macrocycle. Journal of Physical Education and Sport, 18(1), 327-334. https://doi.org/10.7752/jpes.2018.s144

Kostiukevych, V., Shchepotina, N., \& Vozniuk, T. (2020). Monitoring and Analyzing of the Attacks of the Football Team. Teoriâ ta Metodika Fizičnogo Vihovannâ, 20(2), 6876. https://doi.org/10.17309/tmfv.2020.2.02

Lago-Peñas, C., Lago-Peñas, S., \& Lago, I. (2019). Player Migration and Soccer Performance. Frontiers in Psychology, (10), 616. https://doi.org/10.3389/fpsyg.2019.00616

Mykhaliuk, Ye. L., Syvolap, V. V., Horokhovskyi, Ye. Yu., \& Potapenko, M. S. (2021). Effect of year-round training on parameters of heart rate variability, central hemodynamics and physical working capacity in short-distance swimmers. Zaporozhye Medical Journal, 23(3), 343-347. https://doi.org/10.14739/2310-1210.2021.3.229452

Namethe, K., Naido, V., \& van Heerden, C. (2021). Students' Motivation for Attending Varsity Football Matches. African Journal of Hospitality Tourism and Leisure, 10(2), 623-638. https://doi.org/10.46222/ajhtl.19770720.122

Poli, R. (2006). Migrations and Trade of African Football Players: Historic, Geographical and Cultural Aspects. Africa Spectrum, 41(3), 393-414. https://www.jstor.org/stable/40175150

Poli, R. (2010). Understanding Globalization Through Football: the New International Division of Labour,
Migratory Channels and Transnational Trade Circuits. International Review for the Sociology of Sport, 45(4), 491506. https://doi.org/10.1177/1012690210370640.

Poli, R. (2019). Sports Globalization (as Exemplified in Football). Science in Olympic Sport, (4), 46-55. https://sportnauka.org.ua/en/wp-content/uploads/nvos/ articles/2019.4_7.pdf

Shchepotina, N., Kostiukevych, V., Asauliuk, I., Stasiuk, V., Vozniuk, T., Dmytrenko, S., \& Adamchuk V. (2021). Management of Training Process of Team Sports Athletes During the Competition Period on the Basis of Programming (Football-Based). Teoriâ ta Metodika Fizičnogo Vihovannâ, 21(2), 142-151.

https://doi.org/10.17309/tmfv.2021.2.07

Sobol, E., Svatyev, A., \& Doroshenko, E. (2021). Indicators of Financial Support for Football Players' Migration in Leading European Leagues. Sportivna nauka ta zdorov'â lûdini, 1(5), 137-148. https://doi.org/10.28925/2664-2069.2021.110

Sobol, E., Svatyev, A., \& Doroshenko, E. (2021). Financial Value of Ukrainian Premier League Clubs in Relationship With Football Migration Indicators. Sportivna nauka ta zdorov'â lûdini, 2(6), 183-195. https://doi.org/10.28925/2664-2069.2021.216

Solntsev, Y.V. (2020). Strategic Management of the Football Industry: dyss. ... dokt. ekon. nauk: spets.: 08.00.05. «ekonomika i upravlenye narodnym khoziaistvom (menedzhment)». M.: 349. [Russian] http://ords.rea.ru/ wp-content/uploads/2020/10/Solntsev.pdf

Storey, D. (2019). National Allegiance and Sporting Citizenship: Identity Choices of «African» Footballers. Sports Geography: New Approaches, Perspectives and Directions, 1, 129-141. https://doi.org/10.1080/17430437.2018.1555228

Sulistiyono, S., Akhiruyanto, A., Primasoni, N., Arjuna, F., Santoso, N., \& Yudhistira, D. (2021). The Effect of 10 Weeks Game Experience Learning (Gel) Based Training on Teamwork, Respect Attitude, Skill and Physical Ability in Young Football Players. Teoriâ ta Metodika Fizičnogo Vihovannâ, 21(2), 173-179. https://doi.org/10.17309/tmfv.2021.2.11

van Campenhout G., \& van Sterkenburg J. (2019). The Diversification of National Football Teams: Using the Idea of Migration Corridors to Explore the Underlying Structures of Nationality Changes Amongst Foreign-Born Players at the Football World Cup. International Review for the Sociology of Sport, 56(1), 36-61. https://doi.org/10.1177/1012690219892849

van Campenhout, G., van Sterkenburg, J., \& Oonk, G. (2019). Has the World Cup become more migratory? A comparative history of foreign-born players in national football teams, c. 1930-2018. Comparative Migration Studies, 7(1), 22. https://doi.org/10.1186/s40878-019-0118-6 


\title{
КОМПЛЕКТАЦІЯ НАЦІОНАЛЬНИХ ЗБІРНИХ КОМАНД
}

З ОБЛІКОМ ФАКТОРІВ КЛУБНОЇ МІГРАЦІЇ ФУТБОЛІСТІВ

\author{
Едуард Соболь ${ }^{1 \mathrm{ABE}}$, Андрій Сватьєв ${ }^{1 \mathrm{CD}}$, Ігор Дорошенко $^{1 \mathrm{CDE}}$, \\ Світлана Кокарева ${ }^{2 B C E}$, Наталя Корж ${ }^{2 B C E}$, Едуард Дорошенко
}

1Запорізький національний університет

${ }^{2}$ Національний університет «Запорізька політехніка»

З3апорізький державний медичний університет

Авторський вклад: А - дизайн дослідження; В - збір даних; C - статаналіз; D - підготовка рукопису; Е - збір коштів

Реферат. Стаття: 8 с., 3 табл., 28 джерел.

Мета дослідження - визначити параметри клубної міграції висококваліфікованих футболістів-«легіонерів» у процесі комплектування національних збірних команд для участі в офіційних міжнародних змаганнях.

Матеріали та методи. Контингент: 496 висококваліфікованих футболістів - учасників групового відбіркового турніру чемпіонату світу 2022 року.

Результати. У складах національних збірних команд-переможців із високими показниками рейтингу UEFA - менше відсоткового співвідношення футболістів«легіонерів», ніж у групи команд-переможців із нижчими показниками рейтингу UEFA: 45,05\% (рейтинг 3,8) та 85,94\% (рейтинг 14,8) відповідно. Показники подвійного громадянства не мають значного впливу на комплектацію національних збірних команд, хоча у збірних команд Уельсу, Туреччини та Шотландії зафіксовано досить високі значення - 9 (32,14\%), 7 (28,00\%) та 5 (20,00\%) футболістів відповідно. Футболісти-«легіонери» 3 шести найрейтинговіших європейських чемпіонатів (Англія, Іспанія, Італія, Німеччина, Франція, Португалія) становлять 87,50\% від загальної кількості футболістів-«легіонерів», які брали участь у групових відбіркових турнірах чемпіонату світу 2022 року.

Висновки. Процеси міграції впливають на розвиток футболу на різних рівнях функціонування: дитячо-юнацького, резервного, студентського, аматорського, напівпрофесійного та професійного. Клубна міграція, яка характерна для висококваліфікованих футболістів-«легіонерів», опосередковано впливає на комплектацію національних збірних команд.

Ключові слова: футбол, міграція, рейтинг, комплектація, збірна.

\section{Information about the authors:}

Sobol Eduard: sobol.apps@gmail.com; https://orcid.org/0000-0002-6351-7272; Department of Physical Culture and Sports, Zaporizhzhia National University, Zhukovsky St, 66, Zaporizhzhia, 69063, Ukraine.

Svatyev Andrii: 29011973@ukr.net; https://orcid.org/0000-0001-9399-1576; Department of Physical Culture and Sports, Zaporizhzhia National University, Zhukovsky St, 66, Zaporizhzhia, 69063, Ukraine.

Doroshenko Igor: metallurg19u@gmail.com; https://orcid.org/0000-0003-0600-2798; Department of Physical Culture and Sports, Zaporizhzhia National University, Zhukovsky St, 66, Zaporizhzhia, 69063, Ukraine.

Kokareva Svitlana: kokarevas@gmail.com; https://orcid.org/0000-0002-3435-4929; Department of Physical Culture, Olympic and non-Olympic sports, National University "Zaporizhzhia Polytechnic”, Zhukovsky St, 64, Zaporizhzhia, 69063, Ukraine

Korzh Nataliya: nata2008korzh@gmail.com; https://orcid.org/0000-0003-0328-200X; Department of Management of Physical Culture and Sport, National University “Zaporizhzhia Polytechnic”, Zhukovsky St, 64, Zaporizhzhia, 69063, Ukraine

Doroshenko Eduard: doroe@ukr.net; https://orcid.org/0000-0001-7624-531X; Department of Physical Rehabilitation, Sports Medicine, Physical Education and Health, Zaporizhzhia State Medical University, Mayakovsky St, 26, Zaporizhzhia, 69035, Ukraine.

Cite this article as: Sobol, E., Svatyev, A., Doroshenko, I., Kokareva, S., Korzh, N., \& Doroshenko, E. (2021). Formation of National Teams Taking into Account the Factors of Football Players' Club Migration. Teoriâ ta Metodika Fizičnogo Vihovannâ, 21(4), 389-396. https://doi.org/10.17309/tmfv.2021.4.15

Received: 01.12.2021. Accepted: 15.12.2021. Published: 25.12.2021

This work is licensed under a Creative Commons Attribution 4.0 International License (http://creativecommons.org/licenses/by/4.0). 